\title{
Omeprazole and ranitidine in treatment of reflux oesophagitis: double blind comparative trial
}

\author{
T HAVELUND, L S LAURSEN, E SKOUBO-KRISTENSEN, B N ANDERSEN, \\ S A PEDERSEN, K B JENSEN, C FENGER, F HANBERG-SØRENSEN, K LAURITSEN
}

\begin{abstract}
One hundred and sixty two patients with endoscopically proved reflux oesophagitis stratified for severity, 66 with grade 1 disease (erythema and friability) and 96 with grade 2 or 3 disease (including erosions or ulcerations), were allocated at random to double blind treatment with omeprazole $\mathbf{4 0} \mathrm{mg}$ in the morning or ranitidine $150 \mathrm{mg}$ twice daily for up to 12 weeks. A patient could be evaluated sooner if symptomatic relief and endoscopically normal mucosa (grade 0) were noted after four to eight weeks' treatment. Patients treated with omeprazole responded significantly more rapidly than those treated with ranitidine $(\mathbf{p}<0.0001)$, cumulative healing rates at four, eight, and 12 weeks being $90 \%$, $100 \%$, and $100 \%$ respectively for those with grade 1 disease and $70 \%, 85 \%$, and $91 \%$ respectively for those with grade 2 or 3 disease in the omeprazole group. Corresponding rates in the ranitidine group were $55 \%, 79 \%$, and $88 \%$ (grade 1 ) and $26 \%$, $44 \%$, and $54 \%$ (grade 2 or 3 ). Relief of the major symptoms of heartburn, regurgitation, and dysphagia and improvements in the histological appearance of the mucosa occurred earlier and were
\end{abstract}

Department of Gastroenterology, Odense University Hospital, DK-5000 Odense, Denmark

T HAVELUND, MD, senior registrar

L S LAURSEN, MD, senior registrar

B N ANDERSEN, MD, senior registrar

S A PEDERSEN, MD, chief surgeon

K B JENSEN, MD, consultant physician

K LAURITSEN, MD, senior registrar

Department of Pathology, Odense University Hospital, DK-5000 Odense, Denmark

C FENGER, MD, chief pathologist

Department of Surgical Gastroenterology, Aarhus County Hospital, Aarhus, Denmark

E SKOUBO-KRISTENSEN, MD, senior registrar

F HANBERG-SØRENSEN, MD, chief surgeon

Correspondence and requests for reprints to: Dr Lauritsen. again more pronounced during treatment with omeprazole than with ranitidine.

This observed superiority of omeprazole $40 \mathrm{mg}$ in the morning over ranitidine $150 \mathrm{mg}$ twice daily in the short term treatment of reflux oesophagitis was obtained without major clinical or biochemical side effects, but further research is needed into longer term use of omeprazole and the effects of the acid inhibition it induces.

\section{Introduction}

Reflux oesophagitis is a major cause of dyspepsia in the Western World, linked to smoking, diet, and obesity. ${ }^{1}$ The most important pathogenetic factor is probably prolonged and repeated mucosal exposure to gastroduodenal contents. Histamine $\mathrm{H}_{2}$ receptor antagonists provide symptomatic relief when compared with placebo, ${ }^{2}$ but over half of all patients still have symptoms and abnormal mucosal pathology after six to eight weeks' treatment. ${ }^{3.5}$ Omeprazole, a substituted benzimidazole which is a potent proton pump inhibitor, ${ }^{6}$ reduces intragastric acidity more effectively than $\mathrm{H}_{2}$ receptor antagonists ${ }^{7}$ and provides faster ulcer healing and pain relief in patients with peptic ulcer disease.$^{8-10}$ Hence omeprazole might be expected to benefit patients with reflux oesophagitis. To test this we carried out a double blind randomised trial of omeprazole $(40 \mathrm{mg}$ in the morning) and ranitidine ( $150 \mathrm{mg}$ twice daily).

\section{Patients and methods}

Outpatients aged 18-80 whose symptoms of gastro-oesophageal reflux were associated with grade 1 endoscopic appearances (erythema and friability) and at least grade 1 histological findings(see below), or alternatively with grade 2 or 3 endoscopic abnormalities (erosions or ulceration), were considered for entry to the study within 14 days after endoscopy provided they did not meet any of the criteria for exclusion. These were oesophageal stricture (grade 4 disease) requiring intervention; oesophageal varices; Barrett's oesophagus (defined as columnar lined epithelium extending more than $3 \mathrm{~cm}$ above the gastro-oesophageal junction and affecting the entire circumference); systemic sclerosis; concomitant gastric or duodenal ulcer; previous oesophageal or gastric surgery except for simple closure of ulcer 
perforation; pregnancy or lactation; concomitant disease likely to complicate the evaluation of the drug such as liver or kidney failure; drug or alcohol abuse; suspected or confirmed malignancy; and clinically relevant pretrial screening values (leucocyte and thrombocyte counts; haemoglobin and serum sodium, potassium, calcium, and creatinine concentrations; alkaline phosphatase and alanine aminotransferase activities; and urinary concentrations of albumin and glucose). Each patient gave informed consent and the trial was approved by the regional ethics committees.

Before entry a clinical history, assessment of reflux symptoms, and physical examination were undertaken. Patients were stratified according to endoscopic findings, one group comprising patients with grade 1 disease, and another comprising patients with grade 2 or grade 3 disease. Within each group patients were randomly assigned (by a computer generated randomisation list stratified for severity and centre in blocks of six) to treatment with either omeprazole, two $20 \mathrm{mg}$ capsules in the morning, or ranitidine, one $150 \mathrm{mg}$ tablet in the morning and one in the evening. Inactive capsules and tablets identical in appearance with the active ones had been prepared so that all patients received the same number of capsules or tablets. In the run in period between endoscopy and entry into the trial the patients received and were allowed free use of an antacid suspension (Balancid, $10 \mathrm{ml}$ sachets, containing aluminium hydroxide, magnesium hydroxide, and magnesium carbonate); during the trial the same antacid was allowed for symptomatic relief, and the amount used was assessed at each visit.

Patients were seen after four weeks (plus or minus three days) for clinical assessment, laboratory screening, and endoscopy with biopsy. Those with an endoscopically normal mucosa (grade 0 ) and complete symptomatic relief stopped medication. In other cases treatment was extended to eight weeks (plus or minus three days), and if the patient remained symptomatic or if endoscopically abnormal mucosal appearances persisted it was continued to a maximum of 12 weeks (plus or minus three days), when final clinical assessment, laboratory screening, and endoscopy with biopsy were done. Endoscopy was omitted at eight and 12 weeks if endoscopically normal mucosa (grade 0) had been seen at the preceding endoscopy. Returned capsules, tablets, and antacid sachets were counted at each visit, and patients later found to have taken less than three quarters of the active drug per study period were regarded as non-compliant with the study protocol.

For symptomatic assessment each of the symptoms-heartburn, re gurgitation, and dysphagia - were scored with a four point scale, similar to gradings previously used (table I) ${ }^{2411}$ Furthermore, at four weeks patients

TABLE I-Grading of symptoms of gastro-oesosphageal reflux

\begin{tabular}{|c|c|c|}
\hline Symptom & Grade & Description \\
\hline \multicolumn{3}{|l|}{ Heartburn: } \\
\hline None & 0 & \\
\hline Mild & 1 & Occasional episodes, not interfering with normal activities \\
\hline Moderate & 2 & Interfering with normal activities \\
\hline Severe & 3 & Constantly interfering with normal activities \\
\hline \multicolumn{3}{|c|}{ Regurgitation: } \\
\hline None & 0 & \\
\hline Mild & 1 & Occasional episodes, not interfering with normal activities \\
\hline Moderate & 2 & Predictable from position or straining \\
\hline Severe & 3 & Associated with pulmonary aspiration \\
\hline \multicolumn{3}{|l|}{ Dysphagia: } \\
\hline None & 0 & \\
\hline Mild & 1 & Occasional episodes, not interfering with normal activities \\
\hline Moderate & 2 & Requiring liquids to clear \\
\hline Severe & 3 & Episodes of obstruction manifested by vomiting \\
\hline
\end{tabular}

were asked to give an overall assessment of their reflux symptoms compared with those at entry by rating the symptoms as completely gone, improved, unchanged, or worse. After each treatment period the patients were asked in a standardised manner about any new complaints.

For histological assessment at least four oesophageal biopsy specimens were taken at each endoscopy, one from each quadrant, and judged according to a four scaled grading ${ }^{3}$ : grade 0 , normal mucosa; grade 1 , basa cell hyperplasia, extension of papillae, and mild inflammatory infiltration; grade 2 massive polymorphonuclear infiltration; and grade 3 , as grade 2 plus evidence of ulceration.

\section{STATISTICS}

The primary measure of efficacy was endoscopic healing (grade 0 , normal mucosa). In planning the trial we estimated healing rates of $60 \%$ for patients with grade 1 appearances and $30 \%$ for those with grade 2 or 3 appearances after four weeks in the ranitidine group and that increases in these rates of 30 percentage points or more would be clinically meaningful. We calculated that roughly 170 patients ( 38 with grade 1 disease and 48 with grade 2 or 3 disease in each treatment group) were needed to ensure that the risk of overlooking such a difference was less than $20 \% .^{12}$ The data were subjected to both a "per protocol analysis"-that is, including only patients who completed an assessment period according to the protocol-and an "intention to treat analysis"- that is, including all patients who entered the study except those who did not have the disease, such as patients in whom the entry biopsy showed a carcinoma. Patients lost to follow up were considered unhealed.

Healing rates were compared with the Mantel-Haenszel test to cover all three time points with endoscopic grade as a covariable. ${ }^{12}$ The $95 \%$ confidence intervals for differences in healing between the treatment groups were also calculated. ${ }^{12}$ A stratified Wilcoxon test was used to analyse single symptoms and histological findings, baseline grades of severity being taken as strata. An overall evaluation of symptoms was analysed with a ridit analysis ${ }^{12}$ with the ranitidine treated patients as the reference group. Other tests used were the $\chi^{2}$ test and the sign test, as appropriate. Only two tailed tests were used. Values of $p<0.05$ were considered significant.

\section{Results}

Between January 1986 and March 1987, 162 patients entered the trial137 from centre 1 (Odense) and 25 from centre 2 (Aarhus). Eighty were allocated to receive omeprazole and 82 to receive ranitidine. As a result of randomisation more smokers were allocated to the omeprazole group; otherwise the treatment groups were well matched for selected patient characteristics (table II). Six additional patients fulfilled the entry criteria but did not wish to participate.

TABLE II-Characteristics of patients in two treatment groups

\begin{tabular}{lcc}
\hline & $\begin{array}{c}\text { Omeprazole } \\
\text { group } \\
(\mathrm{n}=80)\end{array}$ & $\begin{array}{c}\text { Ranitidine } \\
\text { group } \\
(\mathrm{n}=82)\end{array}$ \\
\hline Sex ratio $(M: \mathrm{F})$ & $48: 32$ & $56: 26$ \\
Mean age in years (range) & $53 \cdot 7(24-79)$ & $54 \cdot 9(22-79)$ \\
Mean duration of history in years (range) & $5 \cdot 7(0-35)$ & $4 \cdot 4(0-30)$ \\
No of smokers & 37 & 25 \\
No with endoscopic grade $(1: 2: 3)$ & $31: 29: 20$ & $35: 28: 19$ \\
No with histologic grade $(0: 1: 2: 3)^{\star}$ & $1: 48: 10: 20$ & $1: 46: 15: 16$ \\
No with heartburn & 79 & 79 \\
No with regurgitation & 69 & 68 \\
No with dysphagia & 41 & 48 \\
\hline
\end{tabular}

^Biopsies not performed in a few cases.

In the ranitidine group one patient was excluded from all analyses because biopsy showed a carcinoma. During the first study period six patients dropped out or were otherwise non-compliant with the protocol (one with healed oesophagitis). During the second study period one patient was withdrawn because of worsening of the symptoms, and two patients (who had dysphagia as the dominant complaint at entry) were withdrawn because dilatation of their impending stricture was now considered appropriate in addition to the medical treatment, which was regarded a failure in the context of the trial. During the third study period one patient (with healed oesophagitis) was withdrawn because of dizziness and four because of noncompliance.

In the omeprazole group three patients were withdrawn during the first study period (one with healed oesophagitis), one because of diarrhoea, one with dry mouth, and one with abdominal cramps; another one did not comply with the protocol; and one was lost to follow up. The cumulative efficacy at week 12 was therefore based on data from 75 patients in the omeprazole group and 67 in the ranitidine group who completed the study according to the protocol.

The duration of treatment-that is, until restoration of normal macroscopic appearances of the oesophageal mucosa associated with complete symptomatic relief or scheduled termination of medication after 12 weekswas four, eight, and 12 weeks for 55,10 , and 10 patients, respectively, in the omeprazole group and 26 , nine, and 32 patients respectively in the ranitidine group $\left(\chi^{2}=21 \cdot 6 ; \mathrm{df}=2 ; \mathrm{p}<0.0001\right)$.

Healing of oesophagitis-Cumulative healing rates were significantly higher in the omeprazole group than in the ranitidine group at any point in the study (table III) regardless of the method of analysis (protocol cohort and intention to treat cohort). Subgroup analysis according to the stratification for endoscopic grade at entry showed a remarkable therapeutic gain among 
patients with the severe disease grades, with a difference in healing rates between treatment groups of $\mathbf{4 0 \%}$ at any time point (table IV). In grade disease ranitidine healed $88 \%$ of patients after 12 weeks; this contrasted with the rapid healing of all patients in the omeprazole group.

Relief of symptoms-The severity of symptoms did not differ between the

TABLE III-Healing of oesophagitis (change to grade 0 ) in patients in two treatment groups (percentages in parentheses)

\begin{tabular}{|c|c|c|c|c|c|}
\hline $\begin{array}{l}\text { Analytical } \\
\text { cohort }\end{array}$ & $\begin{array}{l}\text { Cumulative } \\
\text { healing } \\
\text { rates }\end{array}$ & $\begin{array}{l}\text { Omeprazole } \\
\text { group }\end{array}$ & $\begin{array}{l}\text { Ranitidine } \\
\text { group }\end{array}$ & $\begin{array}{c}\% \text { Difference } \\
(95 \% \text { confidence } \\
\text { interval })\end{array}$ & p Value* \\
\hline Protocol cohort & $\begin{array}{r}4 \text { Weeks } \\
8 \text { Weeks } \\
12 \text { Weeks }\end{array}$ & $\begin{array}{l}58 / 75(77) \\
68 / 75(91) \\
71 / 75(95)\end{array}$ & $\begin{array}{l}29 / 75(39) \\
43 / 72(60) \\
47 / 67(70)\end{array}$ & $\left.\begin{array}{l}38(23 \text { to } 53) \\
31(18 \text { to } 44) \\
25(13 \text { to } 37)\end{array}\right\}$ & $<0.0001$ \\
\hline $\begin{array}{l}\text { Intention to } \\
\text { treat cohort }\end{array}$ & $\begin{array}{r}4 \text { Weeks } \\
8 \text { Weeks } \\
12 \text { Weeks }\end{array}$ & $\begin{array}{l}59 / 80(74) \\
69 / 80(86) \\
72 / 80(90)\end{array}$ & $\begin{array}{l}30 / 81(37) \\
44 / 81(54) \\
49 / 81(60)\end{array}$ & $\left.\begin{array}{l}37(22 \text { to } 52) \\
32(18 \text { to } 46) \\
30(17 \text { to } 43)\end{array}\right\}$ & $<0.0001$ \\
\hline
\end{tabular}

^Mantel-Haenszel test using endoscopic grade as a covariable.

TABLE IV-Healing of oesophagitis (change to grade 0) in patients in two treatment groups (percentages in parentheses) stratified according to endoscopic grade at entry

\begin{tabular}{lccc}
\hline $\begin{array}{l}\text { Analytical } \\
\text { cohort }\end{array}$ & $\begin{array}{c}\text { Cumulative } \\
\text { healing rates }\end{array}$ & $\begin{array}{c}\text { Omeprazole } \\
\text { group }\end{array}$ & $\begin{array}{c}\text { Ranitidine } \\
\text { group }\end{array}$ \\
\hline & $\begin{array}{c}\text { Endoscopic grade I } \\
\text { Protocol cohort }\end{array}$ & & \\
& 8 Weeks & $26 / 29(90)$ & $18 / 33(55)$ \\
& 12 Weeks & $29 / 29(100)$ & $26 / 33(79)$ \\
Intention to treat cohort & 4 Weeks & $29 / 29(100)$ & $28 / 32(88)$ \\
& 8 Weeks & $26 / 31(84)$ & $18 / 35(51)$ \\
& 12 Weeks & $29 / 31(94)$ & $26 / 35(74)$ \\
Protocol cohort & Endoscopic grade 2 or 3 & $28 / 35(80)$ \\
& 4 Weeks & $32 / 46(70)$ & $11 / 42(26)$ \\
Intention to treat cohort & 8 Weeks & $39 / 46(85)$ & $17 / 39(44)$ \\
& 12 Weeks & $42 / 46(91)$ & $19 / 35(54)$ \\
& 4 Weeks & $33 / 49(67)$ & $12 / 46(26)$ \\
& 8 Weeks & $40 / 49(82)$ & $18 / 46(39)$ \\
& 12 Weeks & $43 / 49(88)$ & $21 / 46(46)$ \\
\hline
\end{tabular}

TABLE V-Comparison of symptoms at entry and after four weeks in patients in two treatment groups (percentages in parentheses)

\begin{tabular}{|c|c|c|c|}
\hline Symptom & $\begin{array}{c}\text { Omeprazole } \\
\text { group }\end{array}$ & $\begin{array}{l}\text { Ranitidine } \\
\text { group }\end{array}$ & $\mathrm{p}$ Valuef \\
\hline \multicolumn{4}{|c|}{ Heartburn } \\
\hline $\begin{array}{l}\text { At entry }{ }^{\star} \text { Mild } \\
\text { Moderate } \\
\text { Severe }\end{array}$ & $\begin{array}{l}14 / 74(19) \\
39 / 74(53) \\
22 / 74(30)\end{array}$ & $\left.\begin{array}{l}11 / 72(15) \\
44 / 72(61) \\
17 / 72(24)\end{array}\right\}$ & NS \\
\hline $\begin{array}{l}\text { After } 4 \text { weeks } \\
\text { None } \\
\text { Mild } \\
\text { Moderate } \\
\text { Severe }\end{array}$ & $\begin{array}{c}61 / 74(82) \\
12 / 74(16) \\
2 / 74(3) \\
0 / 74(0)\end{array}$ & $\begin{array}{c}30 / 72(42) \\
23 / 72(32) \\
16 / 72(22) \\
3 / 72(4)\end{array}$ & $<0.001$ \\
\hline \multicolumn{4}{|c|}{ Regurgitation } \\
\hline $\begin{array}{l}\text { At entry }{ }^{\star} \text { : } \\
\text { Mild } \\
\text { Moderate } \\
\text { Severe }\end{array}$ & $\begin{array}{c}21 / 66(32) \\
37 / 66(56) \\
8 / 66(12)\end{array}$ & $\left.\begin{array}{r}27 / 64(42) \\
30 / 64(47) \\
7 / 64(11)\end{array}\right\}$ & NS \\
\hline $\begin{array}{l}\text { After } 4 \text { weeks } \\
\text { None } \\
\text { Mild } \\
\text { Moderate } \\
\text { Severe }\end{array}$ & $\begin{array}{c}57 / 66(86) \\
9 / 66(14) \\
0 / 66(0) \\
0 / 66(0)\end{array}$ & $\left.\begin{array}{c}31 / 64(48) \\
18 / 64(28) \\
13 / 64(20) \\
2 / 64(3)\end{array}\right\}$ & $<0.001$ \\
\hline \multicolumn{4}{|c|}{ Dysphagia } \\
\hline $\begin{array}{l}\text { At entry^: } \\
\text { Mild } \\
\text { Moderate } \\
\text { Severe }\end{array}$ & $\begin{array}{r}22 / 39(56) \\
7 / 39(18) \\
10 / 39(26)\end{array}$ & $\left.\begin{array}{r}22 / 43(51) \\
16 / 43(37) \\
5 / 43(12)\end{array}\right\}$ & NS \\
\hline $\begin{array}{l}\text { After } 4 \text { weeks } \\
\text { None } \\
\text { Mild } \\
\text { Moderate } \\
\text { Severe }\end{array}$ & $\begin{array}{c}33 / 39(85) \\
3 / 39(8) \\
0 / 39(0) \\
3 / 39(8)\end{array}$ & $\left.\begin{array}{c}20 / 43(47) \\
16 / 43(37) \\
4 / 43(9) \\
3 / 43(7)\end{array}\right\}$ & $<0.01$ \\
\hline
\end{tabular}

\# Numbers of evaluable patients presenting that symptom at entry.

†Stratified Wilcoxon test using baseline grades as strata. groups at entry. The severity of heartburn, regurgitation, and dysphagia however, was more reduced after four weeks in the omeprazole group than in the ranitidine group (table V). Patients in the omeprazole group used a median of four adjuvant antacid sachets (50\% interquartile range: $0-22$ sachets) compared with 25 in the ranitidine group (50\% interquartile range: 4-41 sachets) $(p<0.001)$. The overall assessment after four weeks showed that the symptoms were completely gone in 51 patients receiving omeprazole, improved in 23 , unchanged in one, and worse in none. In the ranitidine group the corresponding figures were $23,34,16$, and two patients $(\mathbf{p}<0.0001)$.

Histological findings-Mucosal inflammation was significantly more reduced in the omeprazole group than in the ranitidine group (table VI). This superiority of omeprazole was also shown in separate analyses of biopsy specimens obtained from patients with endoscopic grade 1 disease and grade 2 or 3 disease.

TABLE VI-Comparison of histological findings at entry and after four weeks in patients in two treatment groups (percentages in parentheses)

\begin{tabular}{|c|c|c|c|}
\hline Histological grade ${ }^{\star}$ & $\begin{array}{l}\text { Omeprazole } \\
\text { group }\end{array}$ & $\begin{array}{l}\text { Ranitidine } \\
\text { group }\end{array}$ & p Valuef \\
\hline $\begin{array}{c}\text { At entry: } \\
\text { Grade 0 } \\
\text { Grade 1 } \\
\text { Grade 2 } \\
\text { Grade } 3\end{array}$ & $\begin{array}{c}1(1) \\
43(59) \\
9(12) \\
20(27)\end{array}$ & $\left.\begin{array}{r}1(1) \\
43(61) \\
15(21) \\
12(17)\end{array}\right\}$ & NS \\
\hline $\begin{array}{l}\text { After } 4 \text { weeks: } \\
\text { Grade } 0 \\
\text { Grade } 1 \\
\text { Grade } 2 \\
\text { Grade } 3\end{array}$ & $\begin{array}{l}39(53) \\
29(40) \\
1(1) \\
4(5)\end{array}$ & $\left.\begin{array}{r}16(23) \\
42(59) \\
5(7) \\
8(11)\end{array}\right\}$ & $<0.001$ \\
\hline
\end{tabular}

^Patients of the protocol cohort less two on omeprazole and four on ranitidine (biopsy specimens not taken or not evaluable).

† Stratified Wilcoxon test using baseline grades as strata.

Side effects and laboratory findings-Among the patients treated with omeprazole the following complaints were reported: dry mouth (two cases), diarrhoea (three), abdominal cramps (one), and a rash (one). Among those treated with ranitidine two complained of diarrhoea and one of dizziness. The laboratory values were analysed for changes in concentrations from entry to the last day of treatment by the sign test, and the pattern of change between treatment groups was compared with the $\chi^{2}$ test. No statistically significant differences were found. In several cases a single value fell outside the reference range for the laboratory concerned, but such abnormalities occurred at random in both treatment groups.

\section{Discussion}

These results show that omeprazole $40 \mathrm{mg}$ in the morning is better than ranitidine $150 \mathrm{mg}$ twice daily in accelerating healing of oesophagitis and bringing symptomatic relief. Any potentially negative impact on the results from the excess number of smokers in the omeprazole group was not evident. The apparent therapeutic gain provided by the more powerful acid suppression during omeprazole treatment ${ }^{7}$ elucidates the importance of acid in the pathogenesis of reflux oesophagitis. Our finding that erosive and ulcerative oesophagitis healed-that is, the mucosa appeared normal on endoscopy-in $91 \%$ of the patients taking omeprazole is in keeping with figures reported in a similar trial using $60 \mathrm{mg}$ of omeprazole in the morning ${ }^{13}$; this agreement also indicates

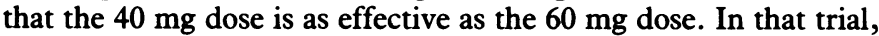
however, mucosal erythema and friability (grade 1 disease) were accepted as healing and no histological data were given. By contrast, our results show that omeprazole treatment is associated with endoscopic, histological, and symptomatic benefit also in patients with grade 1 disease, the endoscopic findings in this group usually being considered less specific than erosions and ulceration. ${ }^{14}$

Although the superiority of omeprazole in our 12 week trial was obtained without any major clinical or biochemical side effects, the management of gastro-oesophageal reflux disease in the long term needs to be assessed. In particular, the gastric neuroendocrine response to profound and sustained acid suppression and subsequent hypergastrinaemia must be clarified. ${ }^{\text {is }}$ Short term treatment with 
omeprazole has not been shown to cause any changes in endocrine cell density, ${ }^{16}$ but further studies are needed to elucidate the possible consequences of prolonged acid inhibition in man.

We thank Mrs Rigmor Petersen and Mrs Grete Eskesen for secretarial help; the staff of our endoscopy units for their valued support; Mr Kjeld Clemmensen-Rotne, Astra-Gruppen A/S, Albertslund, Denmark, for skilfully monitoring the conduct of the study; and A B Hässle, Mölndal, Sweden, for the study drugs.

\section{References}

1 Gledhill T, Hunt RH. Oesophagitis and hiatus hernia. In: Misiewicz JJ, Pounder RE, Venables CW, eds. Diseases of the gut and pancreas. Oxford: Blackwell, 1987:137-51.

2 Johansson K-E, Boeryd B, Johansson K, Tibbling L. Double-blind crossover study of ranitidine and placebo in gastro-oesophageal reflux disease. Scand $\mathcal{F}$ Gastroenterol 1986;21:769-78.

3 Wesdorp E, Bartelsman J, Pape K, Dekker W, Tytgat GN. Oral cimetidine in reflux esophagitis: a double blind controlled trial. Gastroenterology 1978;74:821-4.

4 Wesdorp ICE, Dekker $W$, Klinkenberg-Knol EC. Treatment of reflux oesophagitis with ranitidine. Gut 1983;24:921-4.
5 Koelz HR, Birchler R, Bretholz A, et al. Healing and relapse of reflux esophagitis during treatment with ranitidine. Gastroenterology 1986;91:1198-205.

6 Clissold SP, Campoli-Richards DM. Omeprazole. A preliminary review of its pharmacodynamic and pharmacokinetic properties, and therapeutic potential in peptic ulcer disease and ZollingerEllison syndrome. Drugs 1986;32:15-47.

7 Walt RP, Gomes M de FA, Word EC, Logan LH, Pounder RE. Effect of daily oral omeprazole on 24 hour intragastric acidity. $\mathrm{Br} M e d ~ f$ 1983;287:12-4.

8 Lauritsen K, Rune SJ, Bytzer P, et al. Effect of omeprazole and cimetidine on duodenal ulcer: a double-blind comparative trial. $N$ Engl F Med 1985;312:958-61.

9 Lauritsen K, Rune SJ, Wulff HR, et al. Effect of omeprazole and cimetidine on prepyloric gastric ulcer: double blind comparative trial. Gut (in press).

10 Bardhan KD, Bianchi Porro G, Bose K, et al. A comparison of two different doses of omeprazole versus ranitidine in treatment of duodenal ulcers. $\mathcal{F}$ Clin Gastroenterol 1986;8:408-13.

11 Schaub N, Meyrick Thomas J, Misiewicz JJ, Lowell D, Trotman IF. Investigation of ranitidine $150 \mathrm{mg}$ bd or $300 \mathrm{mg}$ bd in the treatment of reflux disease. Hepatogastroenterology 1986;33: 208-13.

12 Fleiss JL. Statistical methods for rates and proportions. New York: Wiley, 1981.

13 Klinkenberg-Knol EC, Jansen JMBJ, Festen HPM, Meuwissen SGM, Lamers CBHW. Doubleblind multicentre comparison of omeprazole and ranitidine in the treatment of reflux cesophagitis. Lancet 1987; $: 349-51$.

14 Sonnenberg A, Lepsien G, Müller-Lissner SA, Koelz HR, Siewert JR, Blum AL. When is esophagitis healed? Esophageal endoscopy, histology and function before and after cimetidine treatment. Dig Dis Sci 1982;27:297-301.

15 Langman MJS. Antisecretory drugs and gastric cancer. Br Med f 1985;290:1850-2.

16 Karvonen A-L, Keyrilainen O, Uusitalo A, et al. Effects of omeprazole in duodenal ulcer patients. Scand $\mathcal{F}$ Gastroenterol 1986;21:449-54.

(Accepted 27 October 1987)

$\frac{0}{2}$

\title{
Upper gastrointestinal Kaposi's sarcoma in patients positive for HIV antibody without cutaneous disease
}

\author{
I G BARRISON, S FOSTER, J W HARRIS, A J PINCHING, J G WALKER
}

\begin{abstract}
Six patients with antibodies to the human immunodeficiency virus (HIV) and with persistent gastrointestinal symptoms of HIV infection but without cutaneous lesions of Kaposi's sarcoma underwent endoscopy. Four also underwent barium meal examination. In all six cases small lesions were seen in the stomach at endoscopy, and histological examination of biopsy specimens taken from the lesions confirmed the diagnosis of Kaposi's sarcoma. The barium meal examinations were reported as normal in three patients and showed oesophageal candidiasis in the fourth.

These findings suggest that Kaposi's sarcoma of the upper gastrointestinal tract is common in patients positive for HIV antibody, even those without cutaneous lesions. Endoscopy, with biopsy of suspicious lesions, is necessary to make the diagnosis and is recommended in all HIV antibody positive patients with persistent upper gastrointestinal symptoms.
\end{abstract}

\section{Introduction}

Infection with human immunodeficiency virus (HIV) results in a wide range of opportunistic infections and tumours, the commonest of which is Kaposi's sarcoma. Two studies have suggested that

\footnotetext{
Departments of Gastroenterology, Clinical Immunology, and Genitourinary Medicine, St Mary's Hospital and Medical School, London W2 INY

I G BARRISON, BSC, MRCP, senior medical registrar

S FOSTER, MRCP, senior registrar in genitourinary medicine

J W HARRIS, FRCP, consultant physician in genitourinary medicine

A J PINCHING, DPHIL, FRCP, senior lecturer in clinical immunology

J G WALKER, MD, FRCP, consultant physician and gastroenterologist

Correspondence to: Dr Barrison.
}

gastrointestinal Kaposi's sarcoma is more likely to be present in this group of patients if there is extensive cutaneous disease. ${ }^{12} \mathrm{We}$ describe six patients positive for HIV antibody without cutaneous disease in whom upper gastrointestinal Kaposi's sarcoma was diagnosed after endoscopy for the investigation of persistent symptoms.

\section{Case reports and methods}

In all six patients, all of them men, the presence of HIV infection was diagnosed by a positive competitive enzyme linked immunosorbent assay (ELISA) for the detection of anti-HIV antibodies (Wellcome) and confirmed by a competitive ELISA system (Abbott). Their associated conditions and reasons for performing endoscopy are shown in the table. Endoscopies were performed by IGB using an Olympus GIF $_{1} \mathrm{~T}_{10}$ fully immersible endoscope. Two to four biopsy specimens were obtained from each lesion using the $5 \mathrm{~mm}$ Olympus biopsy forceps. Cutaneous Kaposi's sarcoma was excluded by at least two clinical examinations by independent observers.

Findings on endoscopy and the results of a barium meal examination (performed in four patients) are shown in the table, and typical endoscopic appearances are shown in the figure. Histological confirmation of the diagnosis of Kaposi's sarcoma was obtained in all six cases. Five of the six patients had oral candidiasis but only three had oesophageal candidiasis. The barium meal examinations were reported as normal in three patients and showed oesophageal candidiasis in the fourth.

\section{Discussion}

These six cases show that upper gastrointestinal Kaposi's sarcoma frequently occurs in HIV antibody positive patients with persistent symptoms in the absence of cutaneous disease. At present the prevalence of gastric Kaposi's sarcoma among HIV antibody positive patients without cutaneous lesions is unknown. We have found lesions in six out of 25 symptomatic patients (26\%) examined to date and in seven out of 13 patients with cutaneous Kaposi's 